\title{
The Impact of Industry's Concentration on Innovation: Evidence from Russia ${ }^{1}$
}

\author{
Anna A. Bykova, \\ Ph.D. in Economics, National Research University Higher School of Economics, Russian Federation; \\ Research fellow at International Laboratory of Intangible-driven Economy119049, Moscow, Shabo- \\ lovka, 26, building 4
}

Keywords: innovation, firm behavior, Schumpeterian hypothesis, inverted U-shape curve, patents, Russia

JEL: O31, D21, G32

\begin{abstract}
In pursuit of economic growth and development, companies have tried to strike a balance between competition and monopoly power. This paper reviews evidence on industrial concentration and its economic consequences (notably firms' performance as measured by innovation output) in the framework of emerging market conditions. Competition theory was built in developed countries under assumptions that do not necessarily fit emerging economies. Our main research question is whether the level of local market concentration influences (and if it does, in which way) innovation activity undertaken by companies operating on emerging markets. Apart from linear associ-
\end{abstract}

ation, the empirical literature suggests that industrial concentration could exhibit an inverted U-relationship as far as its link to certain economic indicators of success, such as innovation output. We measure concentration by using the Herfindahl-Hirshman Index. This paper finds empirical evidence in support of the Schumpeterian hypothesis that more concentrated industries stimulate innovation and observe the inverted U-relationship curve. Further, the empirical model demonstrates the relative importance of technological leadership in concentration industries to enhance innovations. This suggests a role for recalibrating firm and industry policies.

\section{Влияние отраслевой концентрации}

\section{на инновационную активность российских компаний}

\section{Быкова Анна Андреевна,}

канд. эконом. наук, Национальный исследовательский университет «Высшая школа экономики»: г. Пермь, ул. Студенческая, 38; научный сотрудник Международной лаборатории экономики нематериальных активов

\footnotetext{
${ }^{1}$ The results of the project "Comparative study of intangible endowment of Russian and EU companies", carried. out within the framework of the Basic Research Program at the National Research University Higher School of Economics (HSE) in 2017, are presented in this work.
} 


\section{Introduction}

Firms from emerging countries face a lot of obstacles on their path to prosperity. Economic theory tells us that competition is an essential factor that determines not only economic growth but also a variety of other features of sustainable development [Boone, 2001]. Nevertheless, the theory we have now was developed on the basis of the experiences of developed markets, with assumptions of the availability of capital markets, low entry barriers and low transaction costs, which are simply not good approximations of the conditions on emerging markets. Therefore, for these firms, the effect of competition is not clear and depends on a variety of factors; hence we should reconsider how and to what extent existing theory applies to underdeveloped economies [Aghion et al., 2009].

Russian manufacturing companies are suffering unprecedented fluctuations caused by the economic crisis of 2008, current political and macroeconomic conditions, which may well turn out to be dramatic in terms of their competitiveness. The issue is going to be more relevant in the framework of the import substitution policy. Many of these changes will have implications for competition and concentration of manufacturing companies. One of the consequences is already apparent in the recent wave of mergers and takeovers and cluster creation [Altenburg et al., 2014]. Besides, increased concentration and the size of new players cause concerns about innovations, financial stability and, finally, competitiveness [Carlin et al., 2004]. In order to judge the implications of these developments, one has to examine the degree of competition and market power of manufacturing firms and to investigate the impact of industry concentration on innovative behavior. Despite a clear consensus in the literature that relates to competition and growth, that growth requires increases in productivity, which is achieved through investments in innovation, for emerging markets one of the most important questions to ask in this discussion is what the effect of competition on innovation is.

The literature on the concentration-innovation link may be divided into two main categories, according to the Schumpeter (1942) and Arrow (1962) paradigms. Schumpeter investigates whether a highly concentrated market causes a high level of innovativeness among larger companies resulting in superior performance [Schumpeter, 1950]. From this point, concentration could contribute more to innovation, productivity, and sustainable growth prospects. Evidence from developed economies mostly agrees with this idea [Baker, Graber-Lutzhoft, 2009]. On the other hand, industrial concentration could also result in the exploitation of market power, weaken the motivation for innovation (due to a lack of competition from rivals), discourage new entrants and perpetuate monopoly profits [Scherer, 1982; Baumol, 1982]. This view is supported by Arrow [Arrow, 1962]. According to him, the more competitive the market is, the more incentives there are for companies to create innovations, which leads to greater performance [Baker, Graber-Lutzhoft,
2009]. Arrow's view was retained by Clarke, who analyzed companies of East European and Central Asian economies and showed that the incentive for $\mathrm{R} \& \mathrm{D}$ expenses is greater in a competitive industry than in a concentrated industry for product innovations [Clarke, 2011]. In recent years, however, relatively few empirical studies with contradictory results have examined competition and concentration in emerging markets despite a large number of papers for developed countries.

The study contributes to this goal by investigating the impact of company position in the industry on innovation output based on the data of Russian manufacturing firms. In order to accomplish this, we analyze theoretical and empirical papers related with the issue focused on emerging markets. Secondly, we estimate the level of concentration in different economic sectors and the power of each company according to their market share and then focus on investigating the role of competition in influencing firm innovation output. Specifically, we seek to answer the following questions: How does competition influence innovation? What is the nature of the relationship, specifically? The second question relates to the prevalent opinion that there is an inverted U-shape relationship between innovation and concentration: starting from a very concentrated market, new entrants will increase competition and incentives to innovate. However, at some point this effect will reverse and more competitors will wear away potential profits from innovation, which will decrease investments in R\&D [Aghion et al., 2005; Onori, 2015]. Moreover, we attempt to compare the situation in Russia to that in the US and European countries.

We use regression analysis to investigate differences in the innovation of firms operating in concentrated markets compared to those operating in non-concentrated ones. We estimate the Herfindahl-Hirschman Index (HHI) as one alternative measure of concentration and take into account the number of firms and their market shares. Innovation output will be measured by counting firm patents. We focus on the Russian manufacturing sector as the example of an emerging economy. In order to test the hypotheses, we use a panel of around 500 Russian manufacturing firms from 2004 to 2011 . The database also contains data on each firm's organization and ownership structure, the level of competition it faces, and the number of patents.

This paper found empirical evidence in support of the Schumpeterian hypothesis. Our results for Russian data are the opposite of what was found by Hou and Robinson [Hou, Robinson, 2006] for United States market data. By contrast, our data showed a significant and positive relationship between concentration and innovation output, measured by a count of patents, as well as a direct relationship between size and innovation. At the same time, in support of Aghion et al. [Aghion et al., 2005] we revealed that different levels of concentration affect innovations in different ways, according to an inverted U-shape curve. Moreover, we discovered the positive interaction effect of concentration and the technological 
level of the company on innovation activity. One of the core policy implications of these results is that a high level of concentration stimulates innovations through networks or clusters (as well as with foreign partners), while overly high concentration as well as overly low concentration lead to low innovation creation.

The rest of the paper is organized as follows. Section 2 presents a brief literature review. Section 3 discusses the framework of the study. Section 4 defines the data and summary statistics and presents the empirical model. Finally, we discuss our main results and conclusions in section 5 .

\section{Theoretical Background}

We examine the relationship between firm innovation and the intensity of competition in the industry. Economic theory confirms that the intensity of competition and, hence, the market power of a particular firm is closely related to industry concentration [Aghion et al., 2009]. This section of the paper is devoted to a theoretical and empirical overview of the concentration-innovation relationship.

\section{Industry Concentration-Innovation Relationship: Views of Arrow and Schumpeter}

As discussed in the previous section, there are two opposite points of view on the concentration-innovation relationship based on the works by Schumpeter and Arrow. According to the Schumpeterian view, concentrated markets with large firms have more incentives and capacities for R\&D expenditures, stressing the importance of market power as a return to innovation output. The Schumpeterian argument is based upon the idea of a lack of rewards from innovation in the case of strong competition and, hence, the absence of incentives to innovate [Schumpeter, 1950]. As was shown by Aghion et al. [Aghion et al., 2008], there are at least two more incentives for large companies working on concentrated markets to invest in R\&D. First, as innovation allows a firm to differentiate its products or achieve significantly lower production costs, which can reduce the level of competition, lower production costs can cause the innovating firm to increase its output, causing competitors to react and lower their output. Aghion calls this the "escape-the-competition effect" [Aghion et al., 2008]. The second reason relates to an incentive to prevent competition: a firm with market power may be able to preserve its market power by innovating to deter the entry of rivals. This view is supported by Littunen and Tohmo, who find that most concentrated industries benefit from high economies of scale or a high level of technology [Littunen, Tohmo, 2003].

Arrow was the first who argued that a monopolist's incentive to innovate is less than that of a competitive firm, because of the monopolist's interest in the status quo [Arrow, 1962]. This fundamental idea comes from the knowledge that a firm generating abnormal profits has an interest in protecting the status quo and is thus less likely to be the instigator of disruptive new technology. In Arrow's words: "The pre-invention monopoly power acts as a strong disincentive to further innovation" [Arrow, 1962]. Therefore, the larger current monopoly profits are, the less incentive the monopolist has to innovate, which generates an "X-inefficiency effect". Blundell et al. found that in developed economies, as concentration and monopoly power raises, the rate of innovation falls [Blundell et al., 1999]. Theoretical models, including those of Chen et al. and Gayle, propose that factors like uncertainty in the innovation process and the strategic relationship between new and existing products may motivate entrants to have a higher level of R\&D expenditures [Chen et al., 2009; Gayle, 2003]. Allen and Gale argue that for most firms in developing countries, the intensity of competition on the product market could be considered a "discipline mechanism": as the intensity of competition increases, a firm's freedom to deviate from efficient investment and innovation policies declines [Allen, Gayle, 2004].

However, the debates on the concentration (competition)-innovation relationship are still open both in theoretical and empirical papers. Based on the Schumpeterian theory, Scherer developed the research by allowing for additional nonlinearities and in a cross-sectional analysis of Fortune 500 firms discovered a significant inverted-U shape [Scherer, 1982]. More recently, Aghion et al. [Aghion et al., 2009] has developed a model which explains both the Schumpeterian hypothesis and the positive effect of market competition on innovative activity. They also have shown that the intensity of competition, measured by entry into an industry, influence efficient and inefficient incumbent companies differently. An increase in the number of participants spurs innovation for more technologically advanced companies, whereas for less efficient ones it reduces innovativeness. Overall, these authors revealed that the relationship between competition and innovative activity can be described by an inverted U-shaped curve. In other words, increased competition increases the incentive to innovate when competition is not intense. However, if the competition level is high, increased competition leads to a reduction of the reward yielded by innovation and it also reduces the incentive to innovate [Aghion et al., 2009]. Following Scherer [Scherer, 1982] and Aghion et al. [Aghion et al., 2009], in this paper we explore a non-monotonic relationship as well.

The relationship between product market competition, when measured as the price-cost margin (Lerner Index) or market concentration (Herfindal-Hirshman Index), depends on the features of different markets [Gilbert, 2006]. Since there are forces both in favor of and against a positive relationship between market power and innovative activity, the result is an empirical matter. To the extent that a pure monopoly is rare in the real world, existing empirical studies have focused on the relationship between market concentration and innovation, with the underlying assumption that firms in more concentrated markets tend to have more market power. The present paper will take the same approach to revisit the empirical evidence on the Schumpeterian hypothesis. 


\section{Empirical Evidence of the Impact of Industrial Concentration upon Company Innovation}

Despite its well-developed work, the theory leaves significant gaps in understanding the effects of market structure on innovation and, hence, it is all the more important to turn to empirical studies. The now extensive empirical literature on industrial concentration and firm performance paints a mixed picture [Baumol et al., 2007]. Of particular interest is the empirical evidence of the effect of the interaction between a market structure and, hence, the level of competition on the innovation output. Apart from the relationship between concentration and innovations, we examine whether or not the link has an inverted U-shape. This section critically reviews the empirical literature on the relationships between innovation and market structure.

Scherer [Scherer, 1982] was the first researcher to analyze the relationship between concentration and the number of patents controlling for technological opportunity by dummy variables for a sample of 48 industries, mainly from the chemical, mechanical engineering and electrical engineering sectors. He found no statistically significant effect of concentration on patents [Scherer, 1982]. In addition, Levin and Reiss [Levin, Reiss, 1988] found a similar inverted- $U$ relationship between the measure of innovative output, constructed based on data from a survey of R\&D executives in 130 industries, and concentration. However, the inclusion of fixed sector and firm effects made the coefficients on concentration and its square statistically insignificant [Levin, Reiss, 1988]. Similar conclusions about the uncertainty of the relationship between competition and innovation are reached by Schmutzler [Schmutzler, 2013], who argues that "an inverse $U$-shaped relation between competition and innovation is not necessarily more likely than a U-shaped relation". They generally support a non-monotonic relationship between competition and innovation, but the presumed inverted- $U$ is robust, with only little variation in the specifications and the indicators used [Schmutzler, 2013]. Nevertheless, for developed countries, the majority of researchers give evidence that the relationship between market structure and firm performance is mostly positive, while the shape is not so obvious. Specifically, the study done by Creusen et al. [Creusen et al., 2006] on the relationship between competition and innovation in the Dutch retail sector also finds a positive relationship, but with no evidence for the existence of an inverted-U. At the same time, Medvedev and Zemplinerova [Medvedev, Zemplinerova, 2005] in a study on the Czech economy found that market concentration reduces innovation. Howitt [Howitt, 2007] observes a positive correlation between product market competition and innovativeness within a firm or industry for the Canadian economy. The implied U-shaped relationship appears counter-intuitive but finds some support in recent theoretic models, e.g., by Schmutzler [Schmutzler, 2013] or Tishler and Milstein [Tishler, Milstein 2009]. But as Gopinath et al. demonstrated, better firm performance may not necessarily be due to increased concentration; rather the latter may simply be a proxy for other factors like the presence of scale economies [Gopinath et al., 2004].

Stimulated by the recent developments in economic theory, data access, and measurement, the papers collected in this issue add important new pieces to the puzzle, bringing one closer to a consistent overall picture. The brief overview of the empirical studies is presented in the Table 1.

Table 1

Empirical studies about influence market power on innovation

$\begin{array}{llll}\text { Author, year } & \begin{array}{l}\text { Innovation measure/ } \\ \text { Concentration measure }\end{array} & \text { Sample } \\ \begin{array}{l}\text { Peroni and Ferreira } \\ (2012)\end{array} & \begin{array}{l}\text { R\&D expenditure/profit } \\ \text { elasticity measure }\end{array} & \begin{array}{l}\text { Complusion } \\ \text { Comprehensive firm } \\ \text { and industry level } \\ \text { data }\end{array} & \begin{array}{l}\text { Positive impact of concentration } \\ \text { No support an inverted }-\mathrm{U}\end{array} \\ \text { relationship }\end{array}$




\begin{tabular}{|c|c|c|c|}
\hline Author, year & $\begin{array}{l}\text { Innovation measure/ } \\
\text { Concentration measure }\end{array}$ & Sample & Conclusion \\
\hline Klerxa et al. (2015) & $\mathrm{R} \& \mathrm{D}$, patents/Boone index & $\begin{array}{l}\text { World Bank } \\
\text { Investment Climate } \\
\text { Survey for } 70 \\
\text { developing countries }\end{array}$ & $\begin{array}{l}\text { Monotonic negative effect of } \\
\text { competition }\end{array}$ \\
\hline Gayle (2003) & $\begin{array}{l}\text { Citation-Weighted } \\
\text { patent, market share/ } \\
\text { Concentration Ratio for } 4 \\
\text { largest shareholders }\end{array}$ & $\begin{array}{l}\text { US manufacturing } \\
\text { firms }\end{array}$ & $\begin{array}{l}\text { Strong evidence of an inverted-U } \\
\text { relationship }\end{array}$ \\
\hline $\begin{array}{l}\text { Hopman and Rojas- } \\
\text { Romagosa (2010) }\end{array}$ & $\begin{array}{l}\text { Competition and } \\
\text { Innovation measures }\end{array}$ & $\begin{array}{l}52 \text { 4-digit industries } \\
\text { in } 23 \text { OECD } \\
\text { countries } \\
(1987-2007)\end{array}$ & Evidence on inverted U-relationship \\
\hline $\begin{array}{l}\text { Gorodnichenko et al. } \\
\text { (2010) }\end{array}$ & $\begin{array}{l}\mathrm{R} \& \mathrm{D} \text { intensity/One minus } \\
\text { the Lerner index }\end{array}$ & $\begin{array}{l}\text { Data on } 27 \text { transition } \\
\text { economies }\end{array}$ & $\begin{array}{l}\text { Positive and significant elasticity, } \\
\text { monotonic relationship }\end{array}$ \\
\hline $\begin{array}{l}\text { Medvedev and } \\
\text { Zemplinerova (2005) }\end{array}$ & $\begin{array}{l}\text { Penetration ratio/ } \\
\text { Herfindahl-Hirschman } \\
\text { index }\end{array}$ & Czech companies & $\begin{array}{l}\text { Firms with market power are the } \\
\text { innovators } \\
\text { No support of an inverted } \\
\text { U-relationship }\end{array}$ \\
\hline Kraft (1989) & $\mathrm{R} \& \mathrm{D} /$ Monopoly power & $\begin{array}{l}\text { West German firms } \\
\text { operating in the } \\
\text { metals industry }\end{array}$ & Competition \\
\hline Carlin et al. (2004) & $\begin{array}{l}\text { Sales growth/Number of } \\
\text { competitors, market power }\end{array}$ & $\begin{array}{l}\text { State-owned firms in } \\
\text { transition countries }\end{array}$ & $\begin{array}{l}\text { Strong positive impact of } \\
\text { concentration on innovative activity }\end{array}$ \\
\hline Creusen et al. (2006) & $\begin{array}{l}\text { Relative profits } \\
\text { measurement/Entry and } \\
\text { exit rate }\end{array}$ & $\begin{array}{l}\text { Dutch retail trade } \\
\text { between } 1993 \text { and } \\
2002\end{array}$ & $\begin{array}{l}\text { Monopolies innovate less than firms } \\
\text { facing few rivals. } \\
\text { There is also some less clear- } \\
\text { cut evidence of an inverted } \\
\text { U-relationship }\end{array}$ \\
\hline $\begin{array}{l}\text { Mairesse and Mulkay } \\
(2007)\end{array}$ & $\mathrm{R} \& \mathrm{D} /$ Gini coefficent & French companies & $\begin{array}{l}\text { Competition induces more } \\
\text { innovation }\end{array}$ \\
\hline $\begin{array}{l}\text { Tingvall and Poldahl } \\
\text { (2006) }\end{array}$ & $\begin{array}{l}\mathrm{R} \& \mathrm{D} / \mathrm{HHI} \text {, price cost } \\
\text { margin }\end{array}$ & US and French firms & $\begin{array}{l}\text { Concentration for US } \\
\text { No evidence for French ones }\end{array}$ \\
\hline
\end{tabular}

The existing empirical studies on this subject face the issue that the relationship between competition and innovation is endogenous [Jaffe, 2000; Hall, Harhoff, 2012]. Moreover, clean and direct measurements of innovation and competition are usually not available in the data field, which can lead to the additional problem of measurement error [Aghion et al., 2014]. Various empirical approaches to the identification of causal relationships between patenting activities and innovation are represented in Murray and Stern [Murray, Stern 2007], Williams [Williams, 2013], Galasso and Schankerman [Galasso, Schankerman 2015].

The analysis of the papers has shown the peculiarities of the issue. The main characteristic of the empirical literature on the innovation-market structure hypothesis is its inconclusiveness. However, the main results could be underlined. First, a number of the studies found evidence of a positive relationship between concentration and innovation, although many authors failed to provide any support for the Schumpeterian hypothesis, both for developed and emerging countries. Second, there is even less evidence of a positive relationship between innovative output and market structure. Overall, support for Schumpeter's hypothesis is weaker when the number of patents rather than R\&D expenditures is used as the innovation measure. The issue appears from the evidence that while the Schumpeterian hypothesis is that innovation is higher in the presence of market power, most of the literature has actually tested different hypotheses, namely that innovation is higher in concentrated markets. The implicit assumption is that market power, i.e., the profit 
margin or mark-up, is greater in concentrated markets. This is not obvious in a situation where market structure is considered an endogenous parameter [Aghion et al., 2014]. Third, many studies investigate the market concentration-competition dilemma by estimating different measures (C4 ratio, Herfindahl-Hirshman Index, Lerner Index) based on industrial level data. Finally, for most of the firms from emerging markets, innovations are not just created through original inventions but also by adopting new means of production, new products and new forms of organization [Gayle, 2003]. Hence, we include not only core inventions but also adoptions into the term innovation. Therefore, we focus on relationship between the company position and power in the industry by using micro-level data and analyzing not only the level of con- centration but also market share and innovation output by estimating the number of patents. In the next part of the paper, we provide the framework for the study.

\section{The Theoretical Framework of the Research}

The literature review suggests the hypotheses according to which innovation is influenced by the industry structure. Our conceptual model is presented in Figure 1. The arguments mentioned as an explanation for the positive influence of industry concentration on innovative behavior is related to the assumption that in highly concentrated industries, large firms possess market power.

Figure 1. The Research Framework

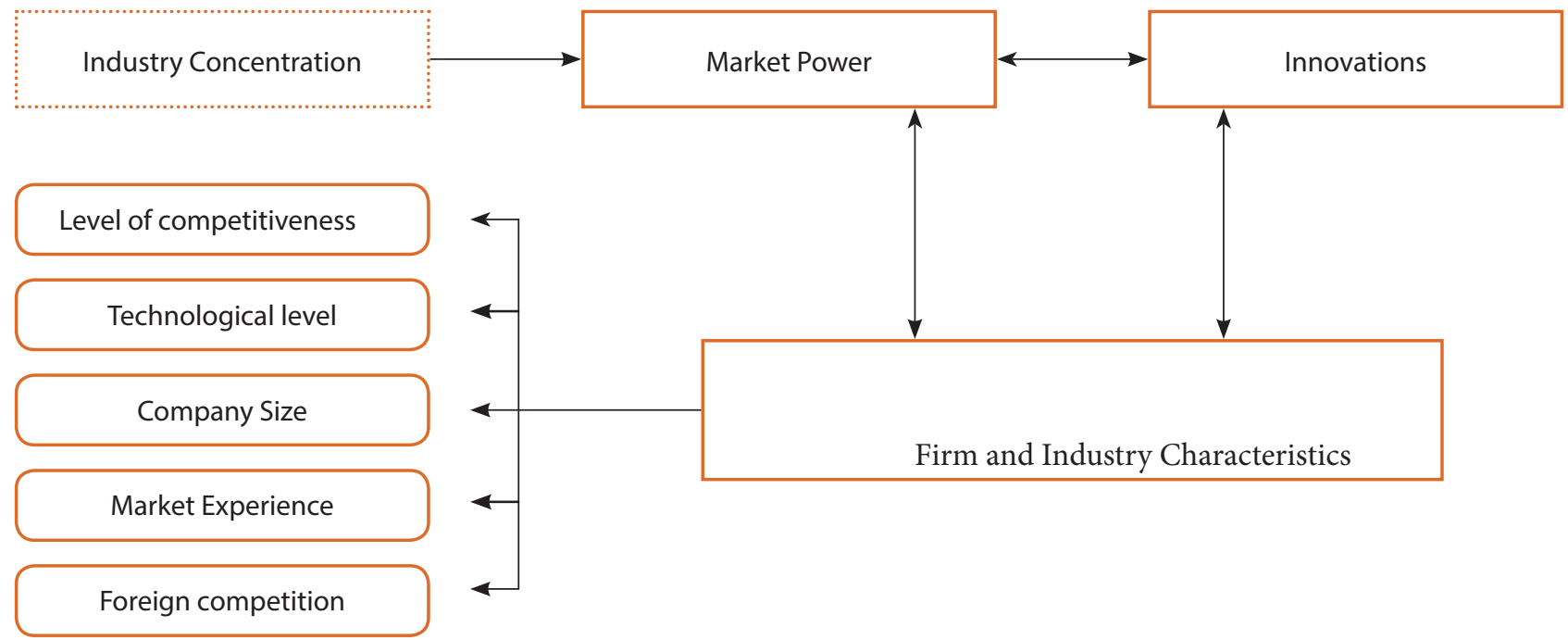

According to empirical papers, different measures for innovation and concentration (or market power) are used. For competition, the most popular are the Lerner Index, price-cost margin, the Herfindahl-Hirshman Index. All of them have strong theoretical backgrounds and reflect different aspects of competition. Although in theoretical models the Lerner Index is defined as

$L I=\frac{P-M C}{P}$

with $\mathrm{P}$ - the price and $\mathrm{MC}$ - the marginal costs of a given product,

in practice the marginal costs cannot be observed, therefore the LI more often is defined as follows:

$L I=\frac{\text { Gross operating surplus }- \text { Financial costs }}{\text { Output }}$

The motivation behind this definition is that it is a (scaled) measure of the profits of firms. The gross operating surplus is large (net of financial costs) compared to turnover, which can be seen as an indication that there is little competition for a firm (or industry/sector), for if there were a lot of competition, firms would lower their prices for a larger market share, which would increase their profits [Creusen et al., 2006].

Closely related to the Lerner index is the markup and its corresponding competition measure, which we define following Griffith et al. [Griffith et al., 2006] as:

$\mu=\frac{\text { Value added }}{\text { Labour costs }+ \text { Capital costs }}$ 
This measure has several advantages over other indicators. These other measures rely more directly on precise definitions of geographic and product markets, which is particularly difficult in our application. A drawback of the price-cost margin is that this measure may point to deviating changes in competition if the underlying determinants of these changes also increase shifts in market shares [Creusen et al., 2006].

In our study, we use the Herfindahl-Hirshman Index measuring the number of firms in an industry and their concentration:

$$
H H I=\sum_{i=1}^{f} S_{i}^{2}
$$

In a perfectly competitive market, HHI approaches zero. In a monopoly, $\mathrm{HHI}$ approaches 10,000 if the single largest firm holds $100 \%$ of the market. In our study we use the synthesized indicator based on HHI estimated for the industries in order to estimate the market power of a company's position:

\section{$M P=H H I^{*}$ Firm Market Share}

where market share is measured based on the percentage of total revenue.

With respect to the innovation indicator, the literature shows a variety of measures of innovations. They can be classified as inputs, typically through the R\&D efforts of firms, or output indices. Measures of innovative output include the number of patents, the number of significant innovations, and various indices of the market value of innovations. There are serious problems with all these measures, however. Attempts to count the number of significant innovations are subject to some uncertainty and possible biases in the evaluation procedure as well as the different level of significance for different innovations. Nevertheless, as Acs et al. noticed, these variables are clearly imperfect proxies for the actual value of innovations [Acs et al., 2004]. Another approach was suggested by Amiti and Khandelwal [Amiti, Khandelwal, 2013], who measure the "quality" of products that are exported from 56 countries to the US, and use that as a proxy for innovation. The quality of a product is an index that consists of information about product price, its market share [Amiti, Khandelwal, 2013]. But the level of analysis is a product, which is not appropriate for our research. Due to these reasons in the paper, following Aghion et al. [Aghion et al., 2009], we apply the number of patents as a measure of innovation output. Gayle [Gayle, 2003] found that innovative activity, as measured by his citation-weighted patent counts, increases with industry concentration. A more modern approach, reflecting the heterogeneous value of patents, assumes the weight of each patent by the number of times it has been cited by another patent. Gayle [Gayle, 2003], however, resuscitated the Schumpeter hypothesis by changing the measure of innovation from simple patent counts to a citation-weighted patent count. He argued that simple patent counts, used by his predecessors, treat technologies covered by patents as equal in their economic and social value [Gayle, 2003]. However, he persuasively argued that the value of individual patents does vary across industries. He argued that his citation-weighted patent counts measure innovation more accurately [Gayle, 2003]. The theoretical relationship between industry concentration and patent activity depends on the reasons why firms have patents. If firms in a particular industry primarily patent to recover their R\&D investment, this is because the characteristics of their technology make patents an effective instrument to obtain monopoly profits, then the industry may become more concentrated as patent activity increases. One of the arguments most frequently put forward to rationalize the hypothesis of the positive effect of market power on innovative activity is that firms with market power can more easily appropriate the returns from their innovations.

H1: The greater market power a firm has, the greater innovations it produces.

Theoretically, it is expected that a positive and non-linear relationship exists between concentration and innovations, so that with an increase in market concentration, initially $\mathrm{R} \& \mathrm{D}$ expenditure increases, but after a certain level of concentration is achieved, the reverse happens. The second hypothesis is based upon the main prediction from the model of Aghion et al. [Aghion et al., 2005]. Their empirical investigation using a panel of UK firms shows an inverted-U relationship between competition and innovation.

H2: Innovation is increasing in competition at low levels of competition and decreasing at higher levels, or there is an inverted U-relationship between competition and innovation.

As was underlined earlier, the strength of the relationship depends on the level of technological development, whether a company is a technological leader or laggard. Aghion et al. [Aghion et al., 2005] predict that firms-leaders are affected the most positively by competition.

H3: Technological leaders demonstrate a more positive relationship between innovation and competition than laggards.

It has long been argued that the relationship between market structure and innovation is not a simple, one-way causal relationship, because market structure is affected by innovative activity. More generally, both variables are endogenously determined within a complex system of interactions with numerous other variables. Recognizing the problem, some authors used instrumental variables for concentration in the context of single equation models, while others estimated simultaneous equation systems in which both innovation and market structure are treated as endogenous. A second difficulty arises with respect to industry-specific characteristics which may be correlated with concentration and may also affect innovation. A number of studies controlled for technological opportunity, appropriability conditions, or both. It is very likely that different industries will have observed levels of patenting activity that have no direct causal relationship with market competition, but reflect other institutional features of the industry. Consequently, industry fixed effects are essen- 
tial to remove any spurious correlation or "endogeneity" of this type. Time effects are also included to remove common macroeconomic shocks and controlling the fact that the determinants of patenting have likely changed over time [Hall, Ham, 2001]. Prior literature has found that the formation of the U.S. Court of Appeals for the Federal Circuit in 1982 created a more patent friendly legal environment resulting in increased patent activity from the mid-1980s through the 1990s [Hall, Ham, 2001].

To explore the relationship between industry concentration and patent activity we use flexible nonlinear estimators to investigate the basic shape of the relationship. In order to test the assumption, we include into the model the interaction term of market power and technological level. Because the number of patents granted to a firm is a count variable, following Hausman et al., [Hausman et al., 1984] and Hall and Ham [Hall, Ham 2001], we use a Poisson-based econometric model and estimation method. We estimate this model using the maximum likelihood for the Poisson distribution with robust standard errors. That is why we hypothesize that the expected number of patents granted $\mathrm{Pi}$ is an exponential function of industry, its concentration $\mathrm{Ci}$, technological level $\mathrm{Zi}$, and other characteristics $\mathrm{Xi}$ in the moment $\mathrm{t}$ :

$$
\begin{aligned}
& \mathrm{E}\left[\mathrm{P}_{\mathrm{it}} \mid \mathrm{C}_{\mathrm{it}}, \mathrm{X}_{\mathrm{it}}, \mathrm{Z}_{\mathrm{it}}\right]=\exp \left(\beta_{0}+\beta_{1} * \mathrm{C}_{\mathrm{it}}+\right. \\
& \left.+\beta_{2} * \mathrm{X}_{\mathrm{it}}+\beta_{3} * \mathrm{Z}_{\mathrm{i}} \mathrm{C}_{\mathrm{i}}+\varepsilon_{\mathrm{it}}\right)
\end{aligned}
$$

For the choice of the relevant firm characteristics, we mostly follow Carlin et al. [Carlin et al., 2004] and Almeida and Fernandes [Almeida, Fernandes 2008], who use similar data sets to analyze innovation. The set of explanatory variables includes the relative technology level, competition, size, age, private and state ownership, exports and imports. In our sample, firm organization and governance are likely to be important predictors of performance. Thus, we track exporters, firms with foreign direct investments (who, in our developing country sample, are likely to be more sophisticated). The latter are likely to be poor competitors based on the findings of earlier literature. Since Schumpeter [Schumpeter, 1950], extended literature has existed relating the rate of innovation to firm size in developed economies. Below, we explore differences across firm size in our sample and treat firm size as a control variable in our tests of the relationship.

The next section is devoted to the empirical part of the research.

\section{The Empirical Study on Concentration-Innovation Relationship The Dataset}

The sample for the study includes annual data about Russian public companies from 2004 to 2011, or 3648 observations. In total, the sample includes $25 \%$ of the companies who engage in export activity. Apart from financial data and intangible proxies, the dataset consists of information about market share as well as estimated HHI on 5-digit industry levels. The final database consists of different kinds of information from various publicly available sources. About $78 \%$ of the sample firms belong to high and medium concentration industries (according to the Herfindal-Hirshman Index definitions); just $13 \%$ belong to high-tech industries (33\% to medium ones).

Table 2 presents the indicators chosen for the model according to the framework based on the previous studies and calculation algorithm.

\section{Table 2}

List of indicators used in the study

\begin{tabular}{|c|c|}
\hline Patents & Number of patents \\
\hline Concentration & $\begin{array}{l}\text { Herfindahl-Hirschman Index }(\mathrm{HHI}) * \text { Total revenue of the company/Total revenue of the } \\
\text { industry (market share) }\end{array}$ \\
\hline Concentration ${ }^{\wedge}$ & $\left(\mathrm{HHI}{ }^{\star} \text { Market share }\right)^{\wedge 2}$ \\
\hline Type of industry & Type of Industry according to OECD classification traditional -0 , high-tech -1 \\
\hline Export & Export presence, yes-1, no- 0 . \\
\hline Foreign Capital Owners & Foreign ownership presence, yes - 1, no - 0 \\
\hline Size & Number of employees, number of people \\
\hline Experience & Number of years since the date of establishment, years \\
\hline Year & Year-dummy for 2008 \\
\hline
\end{tabular}

\section{Name of the indicators Description of variable}

All data were subjected to panel data analytic techniques using the statistical package Stata 12.0. To test the hypotheses, econometric procedures are used. The next part of the paper is devoted to the results of the testing of the hypotheses. 


\subsection{Empirical findings}

This section presents the empirical evidence of the impact of intangibles on the relationship between exports and company performance.

In our sample (Table 3), representatives of Russian manufacturing companies are relatively large, regardless of size measurement criteria (the number of employees and total assets), have positive financial outcomes measured by ROE, ROA and operation margin on average. As expected, the figures in Table 3 prove the huge heterogeneity of the companies within the sample. One reason for this differentiation is the different innovation behavior.

\section{Table 3}

Descriptive statistics of the sample

\begin{tabular}{|c|c|c|c|c|}
\hline Variable & Mean & Std. Dev. & Min & Max \\
\hline Age & 57 & 57 & 0 & 289 \\
\hline Number of Employees & 5258 & 4785 & 36 & 24713 \\
\hline Intangible Assets & 35.67 & 304.50 & 0.00 & 6616.23 \\
\hline Capex & 24.21 & 67.15 & -155.75 & 563.88 \\
\hline Operation Margin & 0.11 & 0.13 & -0.57 & 0.70 \\
\hline Patents & 58 & 158 & 0 & 1292 \\
\hline ROA & 0.09 & 0.11 & -0.27 & 0.78 \\
\hline $\mathrm{ROE}$ & 18.35 & 23.72 & -8.62 & 99.59 \\
\hline Productivity (Sales per employee) & 0.22 & 1.22 & 0.00 & 13.47 \\
\hline
\end{tabular}

Table 4 shows summary statistics for the main variables and the conclusion of the equality test of the means, by concentration categories. As regards the firm market power, the groups significantly statistically differ from each other by many indicators, expressing the heterogeneity of the groups. According to the HHI meanings, $31 \%$ of companies operate in high, $47 \%$ - in medium, $22 \%$ - in low concentrated markets. On average, firms from high concentration industries are larger, both in terms of financial performance and employment. About 50\% of the sample represents low tech industries, while only $14 \%$ of companies work in high-tech sectors. Finally, whatever the industry structure is, investments in intangible assets measured by capital expenditures as a proxy are not significantly different. At the same time, it is interesting to note that, contrary to our main hypothesis, according to the definition of count patents, firms from more competitive industries have more patents than from imperfect ones.

\section{Table 4}

Descriptive statistics for qualitative variables: low and high concentration industries

\begin{tabular}{|c|c|c|c|}
\hline Variable & $\begin{array}{l}\text { Mean for low } \\
\text { concentration }\end{array}$ & $\begin{array}{l}\text { Mean for high } \\
\text { concentration }\end{array}$ & $\operatorname{Pr}(|T|>|t|)$ \\
\hline Intangible assets & 0,72 & 5,11 & 0.04 \\
\hline Number of employees & 5165,00 & 8207,00 & 0.00 \\
\hline Age & 69,00 & 58,00 & 0.00 \\
\hline Capex & 13,89 & 21,60 & 0.14 \\
\hline Patents & 35,05 & 26,57 & 0.00 \\
\hline $\mathrm{ROA}$ & 0,05 & 0,08 & 0.05 \\
\hline ROE & 13,21 & 20,55 & 0.32 \\
\hline
\end{tabular}

We started our analysis with an investigation of the correlation matrix to check whether our sample presents the problem of multicollinearity. All calculations, as seen from Table 5, suggest no major multicollinearity issues for the variables. 
Table 5

Matrix of pairwise correlations between variables

\begin{tabular}{|c|c|c|c|c|c|c|c|}
\hline & $\begin{array}{l}\text { Mar. } \\
\text { Power }\end{array}$ & $\begin{array}{l}\text { Mar. } \\
\text { Power2 }\end{array}$ & $\begin{array}{l}\text { Tecn. } \\
\text { level }\end{array}$ & Exper. & Export & FDI & Empl \\
\hline Market Power & 1.000 & & & & & & \\
\hline Market Power ${ }^{2}$ & $\begin{array}{l}1.000 \\
(0.000)\end{array}$ & 1.000 & & & & & \\
\hline $\begin{array}{l}\text { Technological level of } \\
\text { industry }\end{array}$ & $\begin{array}{l}0.492 \\
(0.000)\end{array}$ & $\begin{array}{l}0.187 \\
(0.000)\end{array}$ & 1.000 & & & & \\
\hline Experience & $\begin{array}{l}-0.125 \\
(0.000)\end{array}$ & $\begin{array}{l}-0.054 \\
(0.514)\end{array}$ & $\begin{array}{l}-0.025 \\
(0.481)\end{array}$ & 1.000 & & & \\
\hline Export & $\begin{array}{l}0.008 \\
(0.826)\end{array}$ & $\begin{array}{l}0.042 \\
(0.225)\end{array}$ & $\begin{array}{l}0.151 \\
(0.000)\end{array}$ & $\begin{array}{l}0.0201 \\
(0.571)\end{array}$ & 1.000 & & \\
\hline FDI & $\begin{array}{l}-0.162 \\
(0.000)\end{array}$ & $\begin{array}{l}0.076 \\
(0.033)\end{array}$ & $\begin{array}{l}-0.226 \\
(0.000)\end{array}$ & $\begin{array}{l}-0.042 \\
(0.233)\end{array}$ & $\begin{array}{l}0.101 \\
(0.004)\end{array}$ & 1.000 & \\
\hline Employees & $\begin{array}{l}0.028 \\
(0.496)\end{array}$ & $\begin{array}{l}0.198 \\
(0.000)\end{array}$ & $\begin{array}{l}0.121 \\
(0.003)\end{array}$ & $\begin{array}{l}(0.038) \\
(0.363)\end{array}$ & $\begin{array}{l}(0.141) \\
(0.001)\end{array}$ & $\begin{array}{l}(-0.135) \\
(0.001)\end{array}$ & 1.000 \\
\hline
\end{tabular}

After that, we run our regression with the interaction effect between market power and technological level controlling for the robustness. The results of tests for the existence of first and second order autocorrelation are taken into account. Table 6 reports the results of regression analysis.

Table 6

The regression results

\begin{tabular}{|c|c|c|c|c|}
\hline Variables & Coefficient & Std. Err. & & $\mathbf{P}>\mathbf{Z}$ \\
\hline Market Power & 0,134 & 0,075 & & 0,073 \\
\hline Market Power ${ }^{2}$ & $-0,390$ & 0,074 & & 0,000 \\
\hline Technological level ${ }^{\star}$ Market power & 0,397 & 0,104 & & 0,000 \\
\hline Experience & 0,002 & 0,000 & & 0,000 \\
\hline Export & 0,088 & 0,063 & & 0,159 \\
\hline Foreign Direct Investments & 0,145 & 0,086 & & 0,091 \\
\hline Number of employees $(\ln )$ & 0,289 & 0,037 & & 0,000 \\
\hline Year 2008 & 0,003 & 0,080 & & 0,967 \\
\hline Constanta & $-1,545$ & 0,308 & & 0,000 \\
\hline Log pseudolikelihood & -740.290 & Pseudo $\mathrm{R}^{2}$ & 0.062 & Number of obs \\
\hline Wald $\operatorname{chi}^{2}(8)$ & 177.020 & Prob $>\mathrm{chi}^{2}$ & 0.000 & 2287 \\
\hline
\end{tabular}

Table 6 shows that the signs of most coefficients of the explanatory variables fit well with the theoretical assertions as depicted above and we accept our hypotheses. In whole, we could conclude that the model is significant but with a low level of explanation power (pseudo $\mathrm{R}^{2}$ is $6 \%$ ). To determine if market power itself, overall, is statistically significant, we applied the two degree-of-freedom chi-square test, which indicates that market power, taken together, is a statistically significant predictor of patents $\left(\mathrm{chi}^{2}(8)=177.02\right.$; Prob $\left.>\mathrm{chi}^{2}=0.000\right)$. For testing the fit of the model, we obtained the goodness-offit chi-squared test. It allows for answering the following question: does the Poisson model form fit our data? As seen in Table 7, we conclude that the model fits well because the test is not statistically significant. 
Table 7

The results of the Goodness-of-fit test

\begin{tabular}{|c|c|c|}
\hline Goodness-of-fit & \multicolumn{2}{|c|}{ Prob $>$ chi $^{2}$} \\
\hline Deviance goodness-of-fit $=419.7847$ & Prob > $\operatorname{chi}^{2}(2256)$ & $=0.6415$ \\
\hline Pearson goodness-of-fit $=307.6358$ & Prob $>\operatorname{chi}^{2}(2256)$ & $=1.0000$ \\
\hline
\end{tabular}

Increases in market power have a significant positive impact on innovations in the Russian manufacturing industry, which means that we accept the H1. Additionally, we have tested the existence of an inverted U-relationship and have supported the theoretical notions of this relationship in $\mathrm{H} 2$ : there is evidence that competition is more positively correlated with innovation at a relatively low level of competition. This can be seen from the positive coefficient of the linear term and the negative square term. In this specification, a marginal increase in competition at high levels of competition seems to be associated with a decline in innovation as would be suggested by the inverted-U hypothesis. This may be appropriate because a large firm has a stronger impact on the competitiveness of the market than a small firm. Being a leader from a technological point of view significantly differs from being a laggard in the case of imperfect competition and the existence of market power, as is shown by the significant interaction effect. This would suggest that leaders do benefit more from competition than laggards in innovation creation, which is in line with $\mathrm{H} 3$. The signs are as expected and the interaction terms lead to a positive number, but there is still only weak evidence that leaders innovate the most. Further, the empirical results also point out that firms with a higher market share, exploring international markets or owned by foreign investors innovate relatively more actively than firms with a lower market share, working on domestic markets only or having local owners. The results obtained in the research have different implications, which will be analyzed in the final part of the paper.

\section{Conclusion}

The purpose of this paper was to analyze how firms' innovation output is related to their position in the industry or their market power. The specifics of the research are dealing with developing markets, where most of the companies are far from the technological frontier and where markets are "historically" concentrated. For the emerging economies, the empirical facts are controversial, while the recommendations have strong practical implications from the industry and company policy view. The effect of the industry structure and on firm innovation is of particular policy interest, since it is likely to be easier to control the amount of incumbents and the openness of the market to competition, than to reform a country's legal and financial institutions [Klerxa et al., 2015]. Following most of the researchers in this topic, we consider measures of industrial concentration as a proxy indicator for competition. In order to match the industrial concentration index with companies we develop a measure multiplying the index and the firm market share.

Our study provided preliminary insights into the relationship between innovation and competition in Russian manufacturing. It found a positive and nonlinear relationship between innovation and concentration, supporting theoretical notions of the existence of an inverted U-relationship. Innovation increases more than proportionately with the firm size because firms with greater market power are better able to finance $\mathrm{R} \& \mathrm{D}$ from their own profits and can more easily appropriate the returns from innovation and hence have better incentives to innovate. What all these mechanisms have in common is the fact that they involve a one-way causality, from market structure to innovative activity.

Due to an inverted U-shape curve, stimulating competition seems therefore encouraging for innovation. One of the concepts which could be applied is a cluster model, assuming the combination of cooperation and competition (it is known as "coopetition"). According to it, there are benefits which the company has when operating in a cluster as sharing large fixed $\mathrm{R} \& \mathrm{D}$ costs and spreading the risks, economies of scale, a better position to exploit unforeseen innovations, and better access to external finance. Moreover, a positive influence of foreign direct investments on innovations allows for considering foreign partners key sources of knowledge. A variety of arguments have been advanced in support of the hypothesis that innovative activity is favored by high concentration and large firm size. Many counterarguments have also been suggested. Some of these involve behavioral characteristics and are hard to test in general, so only circumstantial evidence on their validity may be available. An example is the notion that market power caused by the absence of competitive pressures may lead to inertia and hence to lower innovative activity.

The results from the analysis of the data has shown that firms that have more advanced technology innovate more if they operate in highly concentrated industries and have a great amount of market power. The result that leaders do innovate more than laggards in concentrated industries, thus, is consistent with the theory. Firm ownership and business organization are also important determinants of firm innovation. Export-oriented firms are, in general, more innovative than domestic and those 
organized in partnerships with foreign investors are more innovative than firms financed by local holders. The identity of the controlling shareholder seems to be particularly important for the introduction of a new technology.

During this research, several limitations rose to the surface. Some of these were known right from the start of this research and some were found during the process, which gives a broad domain for future investigation. One of them is testing the "incomplete" relationship - only between concentration and innovation. Evidence from emerging markets demonstrates the unclear assertion that competition may directly encourage firms to attain higher productivity levels by innovating. However, the general idea that innovation is an important driver behind productivity growth is supported. Combining the positive impact of innovation on productivity with the positive impact of competition on innovation suggests that competition has a secondary indirect effect on productivity growth via innovation. If competition leads to higher innovation incentives, indeed, the initial effect of competition on productivity becomes even stronger in the long term. The second issue concerns the severe endogeneity problem, since firms may have market power because they are innovative. More precise measures could be used to fix the problem. The main problems with patent counts are that patents differ greatly in their economic value and that the propensity to patent varies significantly across industries. Measures of supplier concentration suffer in particular from the difficulty to draw appropriate boundaries between different markets. Moreover, most firms within the same industry classification do not compete for the same businesses. Typically, heterogeneous firms specialize in different products and services, quality segments, or geographic areas, even if they belong to the same industry classification at very low levels of aggregation. On the other hand, in most cases competition through imports from suppliers abroad is not considered.

\section{References}

1. Acs Z.J., Audretsch D.B., Braunerhjelm P., Carlsson B. (2004) The knowledge spillover theory of entrepreneurship. Small Business Economics, vol. 32, pp. 15-30.

2. Aghion P., Bechtold S., Cassari S., Herzf H. (2014) The causal effects of competition on innovation: Experimental evidence. Working paper, National Bureau of Economic Research.

3. Aghion P., Bloom N., Blundell R., Griffith R., Howitt P. (2005) Competition and innovation: An inverted-U relationship. Quarterly Journal of Economics, vol. 120, no. 2, pp. 701-728.

4. Aghion P., Blundell R., Griffith R., Howitt P., Prantl S. (2009) The effects of entry on incumbent innovation and productivity. The Review of Economics and Statistics, vol. 91, no. 1, pp. 20-32.

5. Aghion P., Braun M., Fedderke J. (2008) Competition and productivity growth in South Africa. Economics of Transition, vol. 16, pp. 741-768.
6. Allen F., Gale D. (2004) Competition and financial stability. Journal of Money, Credit and Banking, vol. 36, no. 3, pp. 453-480.

7. Almeida R., Fernandes A.M. (2008) Openness and technological innovations in developing countries: Evidence from firm-level surveys. Journal of Development Studies, vol. 44, no. 5, pp. 701-727.

8. Altenburg T., Hillebrand W., Meyer-Stamer Y. (2014) Building systemic competitiveness. Concept and case studies from Mexico, Brazil, Paraguay, Korea, and Thailand. Berlin, German Development Institute. Available at: http://www.meyer-stamer.de/1998/ sysco98.pdf (accessed: 12.01.2015).

9. Amiti M., Khandelwal A.K. (2013) Import competition and quality upgrading. The Review of Economics and Statistics, vol. 95, no. 2, pp. 476-490.

10. Arrow K.J. (1962) The economic implications of learning by doing. Review of Economic Studies, vol. 29, no. 3, pp. 155-173.

11. Baker D., Graber-Lutzhoft K. (2009) Concentration in agribusiness and marketing: A case study of Arla Foods. In Pinstrup-Andersen P., Cheng F. (eds.). Case studies in food policy for developing countries. Ithaca, New York, Cornell University Press, vol. 2, pp. 7-22.

12. Baumol W.J. (1982) Contestable markets: An uprising in the theory of industry structure. American Economic Review, vol. 72, no. 1, pp. 1-15.

13. Baumol W.J., Litan R.E., Schramm C.J. (2007) Sustaining entrepreneurial capitalism. Capitalism and Society, vol. 2, no. 2, art. 1.

14. Blundell R., Griffith R., Van Reenen J. (1999) Market share, market value, and innovation in a panel of British manufacturing firms. Review of Economic Studies, vol. 66, no. 3, pp. 529-554.

15. Boone J. (2001) Intensity of competition and the incentive to innovate. International Journal of Industrial Organization, vol. 19, no. 5, pp. 705-726.

16. Carlin W., Schaffer M., Seabright P. (2004) A minimum of rivalry: Evidence from transition economies on the importance of competition for innovation and growth. Journal of Economic Analysis and Policy: Contributions, vol. 3, no. 1, pp. $1-43$.

17. Chen M., Lin H., Michel J.G. (2009) Prospering in a hypercompetitive environment: The roles of TMT dynamics and competitive behavior. Academy of Management, vol. 4.

18. Clarke G.R.G. (2011) Competition policy and innovation in developing countries: Empirical evidence. International Journal of Economics and Finance, vol. 3, no. 3, pp. 38-49.

19. Creusen H.B., Vroomen H., Kuypers F. (2006) Dutch retail trade on the rise?: Relation between competition, innovation, and productivity. $\mathrm{CPB}$ Document 137, CPB Netherlands Bureau for Economic Policy Analysis. 
20. Galasso A., Schankerman M. (2015) Patents and cumulative innovation: Causal evidence from the Courts Alberto. Quarterly Journal of Economics, vol. 130, no. 1, pp. 317-369.

21. Gayle P.G. (2003) Market concentration and innovation: New empirical evidence on the Schumpeterian hypothesis. KSU Publications, vol. 1, pp. 1-33.

22. Gilbert R.G. (2006) Competition and innovation. Journal of Industrial Organization Education, vol. 1, no. 1, pp. 1-23.

23. Gopinath M., Pick D., Li Y. (2004) An empirical analysis of productivity growth and industrial concentration in us manufacturing. Applied Economics, vol. 36,no. 1, pp. 1-7.

24. Gorodnichenko Y., Svejnar J., Terrell K. (2010) Globalization and innovation in emerging markets. American Economic Journal: Macroeconomics, vol. 2, no. 2, pp. 194-226.

25. Griffith R., Huergo E., Mairesse J., Peters B. (2006) Innovation and productivity across four European countries. Oxford Review of Economic Policy, vol. 22, no. 4, pp. 483-498.

26. Hall B.H., Ham Z.R. (2001) The patent paradox revisited: An empirical study of patenting in the U.S. semiconductor industry, 1979-1995. RAND Journal of Economics, vol. 32, no. 1, pp. 101-128.

27. Hall B.H., Harhoff D. (2012) Recent research on the economics of patents. NBER Working Papers 17773, National Bureau of Economic Research.

28. Hausman J., Hall B.Y., Griliches Z. (1984) Econometric models for count data with an application to the patents- $\mathrm{R} \& \mathrm{D}$ relationship. Econometrica, vol. 52, no. 4, pp. 909-938.

29. Hopman C., Rojas-Romagosa H. (2010) The relation between competition and innovation: Empirical results and implementation into WorldScan. CPB Netherlands Bureau for Economic Policy Analysis, CPB Document 242.

30. Hou K., Robinson D.T. (2006) Industry concentration and average stock returns. The Journal of Finance, vol. 61, pp. 1927-1956.

31. Howitt P. (2007) Innovation, competition, and growth: A Schumpeterian perspective on Canada's economy. C.D. Howe Institute Commentary, vol. 246.

32. Jaffe A.B. (2000) The U.S. patent system in transition: policy innovation and the innovation process. Research Policy, vol. 29, no. 4-5, pp. 531-557.

33. Klerkxa L., Alvarez R., Roberto L., Campusano R. (2015) The emergence and functioning of innovation intermediaries in maturing innovation systems. The case of Chile Innovation and Development, vol. 5, no. 1, pp. 73-91.

34. Kraft K. (1989) Market structure, firm characteristics, and innovative activity. Journal of Industrial Economics, vol. 37, pp. 327-336.
35. Levin R.C., Reiss P.C. (1988) Cost-reducing and demand-creating R\&D with spillovers. RAND Journal of Economics, vol. 19, no. 4, pp. 403-431.

36. Littunen H., Tohmo T. (2003) The high growth in new metal-based manufacturing and business service Firms in Finland. Small Business Economics, vol. 21, no. 2, pp. 187-200.

37. Mairesse J., Mulkay B. (2007) An exploration of local R\&D spillovers in France. Annals of Economics and Statistics, vol. 87-88, pp. 145-166.

38. Medvedev A., Zemplinerova A. (2005) Does competition improve performance? Evidence from the Czech manufacturing industries. Prague Economic Papers, vol. 2005, no. 4, pp. 317-330.

39. Murray F., Stern S. (2007) Do formal intellectual property rights hinder the free flow of scientific knowledge? An empirical test of the anti-commons hypothesis. Journal of Economic Behavior and Organization, vol. 63, pp. 648-687.

40. Okada Y. (2005) Competition and productivity in Japanese manufacturing industries. NBER Working Paper no. 11540.

41. Onori D. (2015) Competition and growth: Reinterpreting their relationship. The Manchester School, vol. 83, pp. 398-422.

42. Peroni C., Ferreira I. (2012) Competition and innovation in Luxembourg. Journal of Industry, Competition and Trade, vol. 12, no. 1, pp. 93-117.

43. Polder M., Veldhuizen E. (2012) Innovation and competition in the Netherlands: Testing the inverted-U for industries and firms. Journal of Industry, Competition and Trade, vol. 12, no. 1, pp. 67-91.

44. Scherer F.M. (1982) Industrial technology flows in the United States. Research Policy, pp. 227-245.

45. Schmutzler A. (2013) Competition and investment - A unified approach. International Journal of Industrial Organization, vol. 31, no. 5, pp. 477-487.

46. Schumpeter J.J. (1950) Capitalism, socialism, and democracy. Harper, New York, 3th ed.

47. Tingvall P.G., Poldahl A. (2006) Is there really an inverted U-shaped relation between competition and R\&D? Economics of Innovation and New Technology, vol. 15, no. 3, pp. 101-118.

48. Tishler A., Milstein I. (2009) R\&D wars and the effects of innovation on the success and survivability of firms in oligopoly markets. International Journal of Industrial Organization, vol. 27, pp. 519-531.

49. Williams H.L. (2013) Intellectual property rights and innovation: Evidence from the human genome. Journal of Political Economy, vol. 121, no. 1, pp. $1-27$. 